\title{
The Dynamics of Moonlighting in Pakistan
}

\author{
ASMA Hyder and ATHER MAQSOOD AHMED
}

\section{INTRODUCTION}

There is substantial amount of literature available in Pakistan focusing on wage level and trends in different sectors of the economy to determine labour market outcomes and differences in the living standard of workers. Irfan (2008) has shown that the time trend growth in wages for the last two and half decades has been 7.7 percent in contrast to 7.2 percent in prices thereby yielding 0.7 percent growth in real wages. This confirms that the purchasing power of consumers has remained very low due to surge in prices of commodities of consumer basket. Unfortunately the economy of Pakistan is facing multiple challenges, starting from its difficulty in arresting the escalation in prices, to achieving sustainable growth in a longer term horizon. There is virtually no improvement in socio-demographic indicators. The labour market dynamics are such that it is becoming increasingly difficult to train and educate people for work and to provide them with decent well-paying jobs. Resultantly, there is a dearth of educated and skilled people, and the mismatch between jobs and workers has increased. In this scenario, those who posses some sort of skills or specific education, they try to get maximum benefit out of it, including holding multiple jobs, even if it involves jobs in other than their own primary occupation.

The moonlighting or holding of dual jobs has not been an attractive agenda of labour economists in Pakistan, even though it has been a common phenomenon in many developing countries. The subject is serious because it not only helps in understanding workers' behaviour and decision to allocate his/her time between work and leisure, moonlighting also affects the very structure of labour market including workers' performance and productivity. An in-depth analysis is therefore, required to know the significance of wage rate, demographics of the labour force, their budget constraints, their engagement in primary and secondary occupations, and above all their human capital characteristics. Given this ambitions agenda, it may not be possible to explore all these issues related with moonlighting in a single study. Therefore, the present study seeks to focus on three main research questions. The first and the main objective of the study is to find out the main determinants of dual job holding; Second, to explore the demographic and human capital characteristics of moonlighters; and lastly, to investigate relationship between workers' main occupation and second job. Within this perspective, the study may be regarded as a starting point to understand the complexities of labour market in Pakistan, particularly the job mobility, labour market transition and spillover over effects, if any.

Asma Hyder<asmabaloch2000@hotmail.com> is Assistant Professor and Ather Maqsood Ahmed <ather_ma@hotmail.com> is Professor in Economics Department at the NUST Business School, Islamabad. 
The organisation of the study is now outlined; next section will provide a review of background studies followed by a section on the facts regarding data and its characteristics. The fourth section presents brief description of the model and methodology adopted in the paper. The fifth section comprises of empirical results and discussion, last section concludes the study based on empirical findings of this paper.

\section{BACKGROUND}

Despite the importance of dual job holding in today's economy, it is difficult to find comprehensive information particularly in terms of empirical evidence in the available economic literature. Despite the fact that dual job holding in labour market is be the result of many integrated reasons, Shishko and Rostker (1976), O'Connell (1979) and Krishnan (1990) have concentrated only on the constraint motives which restrict the working hours on the primary job and limits the earning capacity. Every rational worker who wants to maximise his/her utility would opt for second job if he/she is not satisfied with hours worked on first job and therefore earning less than his reservation wage. Paxson and Sicherman (1994) characterise dual-jobs and dual-job holders, with a focus on dynamics. The aim of their study was to understand why and when workers moved into and out of second jobs. Kimmel and Conway (1995) presented a diverse work which examined the characteristics of moonlighters and also the length of this episode. The analysis of their article reveals that most moonlighters, in spite of working long hours, tended to be poorer than the average worker. Berman and Cuizon (2004) placed multiple job holdings in the context of health systems and government policies in low and middle-income countries. The paper offered guidance on how policy-makers could deal with both the positive and negative view of multiple job holdings. A bivariate probit model of the decision to work and the decision to hold more than one job was estimated by Averett (2001), where she found that there was no difference in factors that influenced the decision to moonlight either by men or women.

\section{DATA}

The study exploits the Labour Force Survey 2006-07 to understand the dynamics of dual job holding in Pakistani Labour Market. To explore this issue we have restricted this study only to male workers residing in urban areas. The reasons for these restrictions are based on different characteristics of rural labour markets; moreover in many cases females are involved in moonlighting but are under reported thus not included in estimation. To capture the residential effect the representation of four provinces is included in the analysis. Since the main aim of the study is to find determinants of moonlighting and relationship between primary and secondary occupation. Thus nine occupational categories along with total hours spent in the labour market are also included in model specification. The definition of the variables and their magnitude both for single and dual job holder are given in Table 1.

The total sample comprises of 17248 male workers living in urban areas, among those 1.3 percent reported as moonlighters. Average age is high for those with dual jobs holding may be due to increasing responsibilities at higher age. Similarly, 90 percent of the dual job holders are married. The average weekly time spent in labour market is definitely high for moonlighters. The data shows that moonlighters are endowed with 
Table 1

Definition and Mean of the Variables

\begin{tabular}{|c|c|c|c|}
\hline \multirow[b]{2}{*}{ Variables } & \multicolumn{3}{|c|}{ Single Job } \\
\hline & Definition & Holders & Moonlighters \\
\hline Age & Age in complete years & $\begin{array}{c}34.52 \\
(11.58)\end{array}$ & $\begin{array}{c}39.94 \\
(10.301)\end{array}$ \\
\hline Hrwork & $\begin{array}{l}\text { Hours spent during one week in Labour } \\
\text { Market (Primary }+ \text { Secondary) } \\
\text { (S.D) }\end{array}$ & $\begin{array}{c}54.15 \\
(10.67)\end{array}$ & $\begin{array}{c}60.73 \\
(11.31)\end{array}$ \\
\hline Wkearn & $\begin{array}{l}\text { Monthly income earned from primary } \\
\text { occupation } \\
\text { (S.D) }\end{array}$ & $\begin{array}{c}1383.99 \\
(1562.28)\end{array}$ & $\begin{array}{c}1425 \\
(1417.26)\end{array}$ \\
\hline MS & Marital Status & .6837 & .9056 \\
\hline School & $\begin{array}{l}\text { Number of years of schooling } \\
\text { (S.D) }\end{array}$ & $\begin{array}{c}8.2373 \\
(5.4053)\end{array}$ & $\begin{array}{c}8.56 \\
(6.02)\end{array}$ \\
\hline Punjab & Dummy if residence is in Punjab & .466 & .4979 \\
\hline Sindh & Dummy if residence is in Sindh & .3075 & .1784 \\
\hline $\begin{array}{l}\text { Khyber } \\
\text { Pakhtunkhwa }\end{array}$ & $\begin{array}{l}\text { Dummy if residence is in Khyber } \\
\text { Pakhtunkhwa }\end{array}$ & .1147 & .2940 \\
\hline Balochistan & Dummy if residence is in Balochistan & .11014 & .0290 \\
\hline Manager & Dummy if Occupational category is Manager & .2736 & .1950 \\
\hline Professional & Dummy if Occupational category is Professional & .0326 & .1161 \\
\hline Technical & $\begin{array}{l}\text { Dummy if Occupational category is } \\
\text { Technical Worker }\end{array}$ & .0619 & .1410 \\
\hline Clerks & $\begin{array}{l}\text { Dummy if Occupational category is Clerical } \\
\text { Staff }\end{array}$ & .0371 & .0622 \\
\hline Service & Dummy if Occupational Category is Service & .1007 & .0705 \\
\hline Skill & $\begin{array}{l}\text { Dummy if Occupational category is Skilled } \\
\text { Worker }\end{array}$ & .0417 & .1244 \\
\hline Craft & $\begin{array}{l}\text { Dummy if Occupational Category is } \\
\text { Craftsman }\end{array}$ & .2281 & .0788 \\
\hline Plant & $\begin{array}{l}\text { Dummy if Occupational Category is Plant } \\
\text { Operator }\end{array}$ & .0730 & .0663 \\
\hline Elementary & $\begin{array}{l}\text { Dummy if Occupational Category is } \\
\text { Elementary }\end{array}$ & .1509 & .1452 \\
\hline Total Sample & & 17248 & 241 \\
\hline
\end{tabular}

higher number of years of schooling. The Labour Force Survey provides educational information in the form of different levels of schooling, which is converted into a continuous variable with number of years of schooling required for each educational level. The raw data indicate that the incidence of moonlighting is highest in Punjab and lowest in Balochistan. The total proportion of workers is high in Sindh but the practice of moonlighting is higher in Khyber Pakhtunkhwa. 
Among the nine occupational categories; managers, technicians and skilled categories have the highest number of moonlighters. The proportion of these categories is low as compared to other categories in overall labour force because these occupation requires specific human capital endowment. The individuals with the specific human capital characteristics are low in supply but demand is high in labour market; thus these people can get involve themselves in multiple jobs in order to utilise their human capital to its maximum level. Thus the overall labour force comprises a small proportion of these occupations but moonlighter are more concentrated in these categories.

\section{MODEL AND METHODOLOGY}

The moonlighting is supply of labour in more than one job. Even though there can be different motives for dual job holding, but labour economists believe ${ }^{1}$ that the most important reason to moonlighting is constraints on working hours in the first job. However the issue becomes complicated once individuals are engaged in two different types of occupation. Thus keeping heterogeneous occupations is also the agenda of this paper.

We start the model using the microeconomic foundation whereby workers drive utility income (earned and non-earned) and leisure. Mathematical it can be stated as,

$$
\begin{array}{lllllllll}
\operatorname{Max} u(Y, l) & \ldots & \ldots & \ldots & \ldots & \ldots & \ldots & \ldots
\end{array}
$$

Subject to: $h_{1}+h_{2}=24-l$ and $w_{1} h_{1}+w_{2} h_{2}=Y$

Where $h_{1}, h_{2}, w_{1}, w_{2}, l$, and $Y$ are hours worked and earnings from primary and secondary $\mathrm{job}^{2}$, leisure, and total income earned from both jobs. By substituting these constraints in the utility function we will obtain:

$$
\begin{array}{llllll}
\operatorname{Max} u\left(w_{1} h_{1}+w_{2} h_{2}, 24-h 1-h 2,\right) & \ldots & \ldots & \ldots & \ldots & \ldots
\end{array}
$$

The constraint of minimum working hour has been applied in estimation. Thus only those individuals working more than 36 working hour ${ }^{3}$ are included in the estimation. The estimation is based on two models, first is probit model to examine the determinants of moonlighting and second model is estimated for the treatment of endogenous regressor. For the correction of possibility of endogeneity instrumental variable probit model is used, which adopts two-step estimation methodology. First model incorporates the effect of total working hours on moonlighting and second model examines the effect of weekly wages from the main occupation on moonlighting.

\section{Model 1}

The probability of holding two jobs is estimated through following model specification, where the dependent is a binary variable and thus probit model is used:

\footnotetext{
${ }^{1}$ Averett (2001), Kimmel and Powell (1999), Krishnan (1990), Paxson and Sicherman (1994), Shishki and Rostker (1976) and Stinson (1990).

2"Y" refers only earned income, non-earned income is not included in out model specification.

${ }^{3}$ According to the definition of ILO those working less than 36 hours are considered as part-time workers. Since the purpose of paper is to explore the issue of moonlighting thus we excluded those working less than 36 hours. Reference: http://www.ilo.org/public/english/protection/condtrav/pdf/infosheets/wt-4.pdf
} 


$$
\log \left(\frac{\text { Prob( } \text { moonlight })}{\text { Prob(will hold one job only })}\right)=X \beta \quad \ldots \quad \ldots \quad \ldots
$$

Or

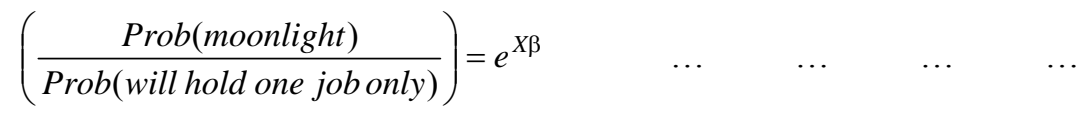

$$
\begin{aligned}
& \operatorname{Prob}\left(\begin{array}{lr}
=1 \text { if } \text { moonlight } \\
=0 & \text { otherwise }
\end{array}\right)=e^{x \beta} /\left(1+e^{x \beta}\right)=[1+\exp (-x \beta)]^{-1} \quad \ldots \quad \ldots
\end{aligned}
$$

The variable determining the probability of holding dual jobs include age, age square, marital status, number of years of schooling, four provincial categories and nine occupational categories are included in this model specification.

\section{Model 2}

When any of the regressors (wages in primary occupation in this case) are endogenous, then estimates are inconsistent [Yatchew and Griliches (1985)]. For this Instrumental Variable Probit (IVP) model method is preferred. The parameters are estimated by maximising the conditional likelihood. This method earlier used by Murphy and Topel (1985) for such type of correction. The following notation has been developed to understand the particular model specification used here.

The original model for the decision of moonlighting is as follows:

$$
\operatorname{Pr}(Y=1 \text { or Zero })=\beta T+\gamma X+\eta W+\mu \quad \ldots \quad \ldots \quad \ldots \quad \ldots
$$

Where $T$ is age, age square, number of years of schooling, $X$ is for marital status, provincial dummies and nine occupational variables. $W$ is for log of weekly wages earned from main occupation. Since wage is endogenous variable, which it-self is determined by age and schooling, therefore it may lead towards biased estimates. The problem of endogeneity is avoided through a two-step instrumental variable probit model method. In first stage, log of wages are estimated as a function of age, age square and number of years of schooling.

$$
\begin{array}{llllllll}
W=\delta T+V & \ldots & \ldots & \ldots & \ldots & \ldots & \ldots & \ldots
\end{array}
$$

Where $T$ includes age, age square and schooling, $V$ is an error term. A new predicted variable is generated (log of weekly wages) based on estimated co-efficient of $T$. In the second stage, the predicted values of log of weekly wages are included in the probit model with rest of demographic, occupational and regional variables. Finally the model (6) gets the form presented in Equation (8). In the final Equation $T$ do not enter in the model rather it enters through predicted wages.

$$
\operatorname{Pr}(Y=1 \text { or Zero })=\gamma X+\eta W_{\text {(predicted) }}+\mu \quad \ldots \quad \ldots \quad \ldots \quad \ldots
$$

The usual probit maximum likelihood procedure is used for the estimation of the parameters. 


\section{EMPIRICAL RESULTS AND ANALYSIS}

Table 2 presents the results of both models i.e., Probit and two step IV Probit model. In both models the dependent is a binary variable and shows the decision of an individual that he/she will moonlight or not. The estimated co-efficient of the model 1 shows that age and being married increases the probability of holding two jobs. The probability of married individual to moonlight is .360 percentage points more as compared to singles. As far as schooling is concerned it is not only insignificant but also very small in magnitude, the reason may be that decision of holding a second job is not necessarily influenced by level of education. There are many illiterate workers in labour market those who are engaged in multiple jobs within elementary occupations. Many workers associated with blue-collar low skilled occupations like security guards, gardeners, drivers, chefs etc are holding more than one job. Secondly it is also evident from summary statistics that average years of schooling is 8.2 years for single job holders and 8.5 for those moonlighters with a comparatively high standard deviation, thus labour supply decision or decision of holding more than one job is not influenced by schooling.

Among all the provincial dummies the probability of moonlighting is higher in rest of three provinces as compared to Balochistan. The most plausible reasons are low rate of economic activity in the province and the proportion of professionals, technicians and related categories where chances of moonlighting are high comprises very low in total labour force in Balochistan. Most of the people are concentrated in elementary occupations or craft related activities. The odd ratio for Khyber Pakhtunkhwa is highest; reason may be the established and vibrant business community, huge share of informal sector, trade and related occupational categories.

We have used occupational categorisation according to international classification system of occupation. 'Professional' category is used as base category, the estimated coefficient shows that the probability of moonlighting is highest for professionals as compared to any other occupation. Annexure A illustrates the sub-categories of professional category; which include science and engineering professionals, health professionals, teaching professionals, business and administration professionals, information and communications technology professionals, legal, social and cultural professionals. The occupational categories require some specific type of education and are high in demand in labour market. Doctors, engineers, lawyers, and business professionals are most popular labour market participants involved in moonlighting. All occupational categories have negative signs and significant except skill category which include occupations related with agriculture and fishery industry; in these occupational categories chances to moonlight are rare.

Another important motive for holding second job is lower wage from primary job as compared to individuals' reservation wage. The wages earned during a week is function of age, experience and schooling; due to the endogenous nature of wage this study used two-step IV Probit model. Many papers propose to use this model in case of endogenous regressors in probit model [see for example: Arendt and Holm (2006)]. In second model the significance and signs of all estimated coefficients remain same; however there are some considerable changes in magnitudes. The log of weekly wages is a predicted variable and it is function of age, age square and number of years of schooling. The log of predicted weekly wages earned from primary occupation are 
insignificant and are low in magnitude, which suggest that as the income earned from the primary occupation do not play a significant role in moonlighting decision. The result is also confirmed by summary statistics Table 2 that average monthly earnings from primary occupation of single job holders is almost same of those have dual jobs with a very high standard deviation. Thus results show that decision to moonlight is not influenced by income from primary occupation, which shows that there are some other reasons are more important. The most probable reason is constraint on working hours on primary job.

Table 2

Probit Result (Dependent Variable: Moonlighting $=1$ if Moonlight and Zero Otherwise)

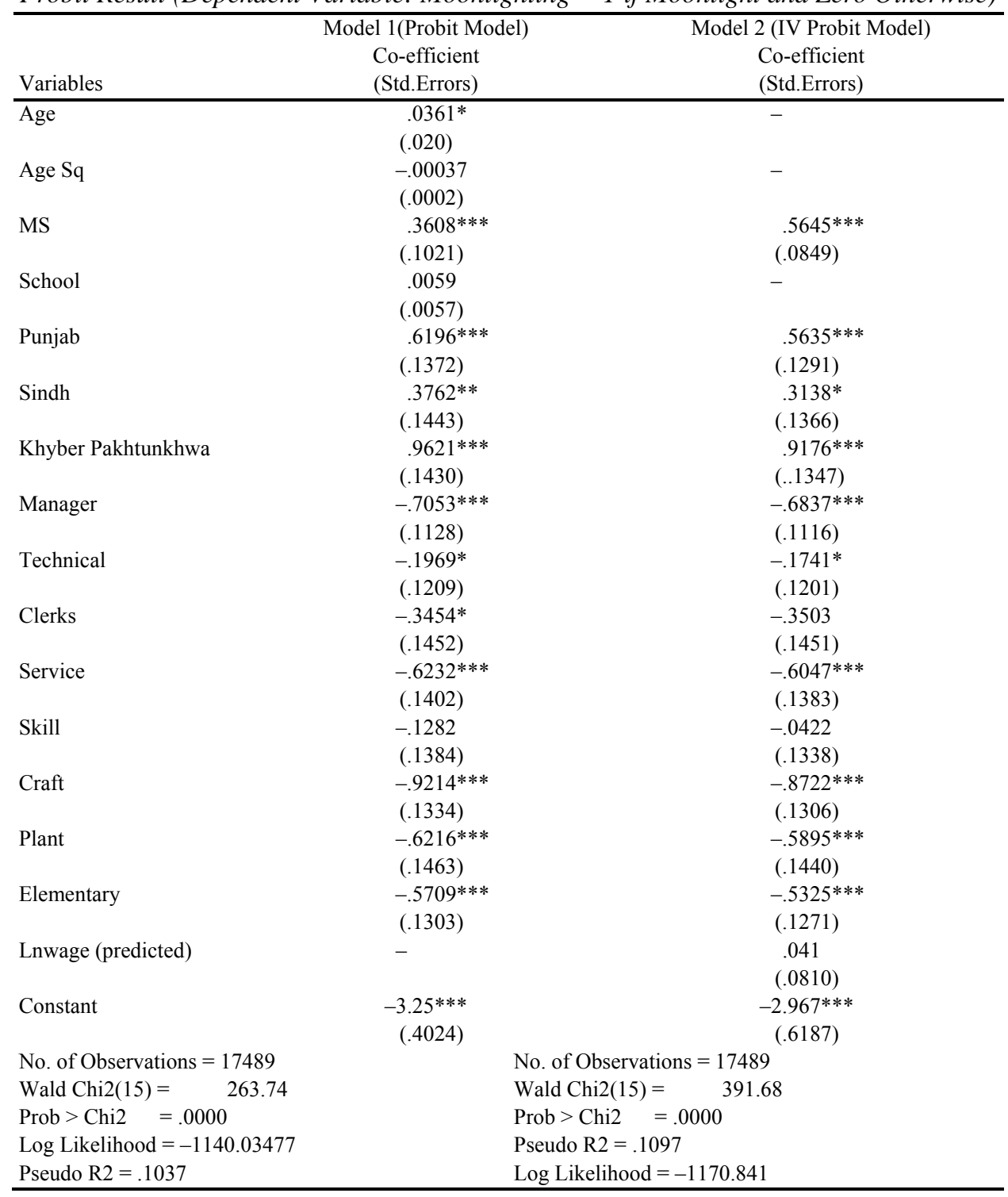


The details of major occupational groups along with their sub-groups are given in Annexure A. Among those moonlighters in managers' category 46.8 percent are holding their second job in market-oriented agriculture and fishery related occupation. Professionals and technicians are only two primary occupations in which dual job holders are moonlighting within their main occupation. According to summary statistics presented in Table 3, there is very small proportion of clerks in the overall labour market. Within those small numbers of workers in this category those with holding two jobs mostly are engaged in first occupational category. Those in 'service' category are more related with craft and related trade occupations in their secondary jobs. Moonlighters both in 'craft' and 'plant' are mostly associated with 'skill' category for their secondary occupation. Thus those workers who opt for different occupation for moonlight, to investigate the spillover effect may be an interesting future research agenda.

Table 3

Occupational Association between Primary Occupation and Secondary Occupation

\begin{tabular}{lccccccccc}
\hline $\begin{array}{l}\text { Sec-Occupation } \\
\text { Main-Occupation }\end{array}$ & $\begin{array}{c}\text { Mana- } \\
\text { ger_2 }\end{array}$ & $\begin{array}{c}\text { Profes- } \\
\text { sional_2 }\end{array}$ & $\begin{array}{c}\text { Tech- } \\
\text { nical_2 }\end{array}$ & Clerk_2 & Service_2 & Skill_2 & Craft_2 & Plant_2 & $\begin{array}{c}\text { Elemen- } \\
\text { tary_2 }\end{array}$ \\
\hline Manager_1 & $12.7 \%$ & $3.12 \%$ & $10.63 \%$ & $0 \%$ & $3.12 \%$ & $48.8 \%$ & $17.02 \%$ & $0 \%$ & $4.2 \%$ \\
Professional_1 & $7.14 \%$ & $67.85 \%$ & $21.42 \%$ & $0 \%$ & $0 \%$ & $0 \%$ & $3.57 \%$ & $0 \%$ & $0 \%$ \\
Technical_1 & $14.28 \%$ & 14.28 & $37.14 \%$ & $0 \%$ & $0 \%$ & $11.42 \%$ & $11.42 \%$ & $5.71 \%$ & $5.71 \%$ \\
Clerks_1 & $53.33 \%$ & $0 \%$ & $6.66 \%$ & $0 \%$ & $6.66 \%$ & $13.33 \%$ & $6.66 \%$ & $13.33 \%$ & $0 \%$ \\
Service_1 & $11.76 \%$ & $5.88 \%$ & $5.88 \%$ & $0 \%$ & $5.88 \%$ & $11.76 \%$ & $29.41 \%$ & $5.88 \%$ & $23.52 \%$ \\
Skill_1 & $26.47 \%$ & $0 \%$ & $5.88 \%$ & $0 \%$ & $0 \%$ & $17.64 \%$ & $0 \%$ & $0 \%$ & $50 \%$ \\
Craft_1 & $20 \%$ & $0 \%$ & $5 \%$ & $0 \%$ & $0 \%$ & $45 \%$ & $25 \%$ & $5 \%$ & $0 \%$ \\
Plant_1 & $31.25 \%$ & $12.5 \%$ & $6.25 \%$ & $0 \%$ & $0 \%$ & $37.5 \%$ & $12.5 \%$ & $0 \%$ & $0 \%$ \\
Elementary_1 & $11.42 \%$ & $0 \%$ & $2.85 \%$ & $0 \%$ & $5.71 \%$ & $31.42 \%$ & $0 \%$ & $2.85 \%$ & $45.71 \%$ \\
\hline
\end{tabular}

Now coming back to the main research questions described earlier in the study. Overall the results show that the being in certain occupations increases the probability to moonlight. There can be number of reasons for this, for example under utilisation of skills and restriction on number of working hours in their primary occupations. The second main question of the study is to explore the characteristics of the moonlighters, the reveals that average age of moonlighters is 40 years, 90 percent are married, on average they have nine years of schooling and 50 percent of total moonlighters are residing in Punjab. Managers, professionals, technicians and elementary occupations are most popular among the moonlighters, or in other words we can say that moonlighters are concentrated on both ends of the occupational distribution. Lastly, the study finds that managers usually moonlight in their own occupational category or in skill category, ${ }^{4}$ professionals moonlight in their own primary occupation, technicians also moonlight in their own occupation but the evidence shows that they also moonlight in managers and professional category.

\section{CONCLUSION}

The study has investigated the dynamics of moonlighters and association between the primary and secondary jobs in Pakistani labour market while exploiting information from Pakistan Labour Force Survey 2006-07. Surprisingly the wage rate is not the 
motivation for incidence of moonlighting, rather individuals reported as moonlighter earning more as compared to those who are relying on one job only. The last part of the analysis presents the association of occupation between primary and secondary occupation, the occupational association analysis shows that only professionals and technicians are two occupational categories where moonlighters are holding their secondary jobs in the same occupation.

The study is constrained by many limitations like unavailability of information on many important variables for example constraint of hours on primary job etc. But the implications of the study are very important; it open many venues for further research on this topic, for example the effect of moonlighting on productivity on first job, labour market transition, job mobility etc.

Annexure A

\section{INTERNATIONAL STANDARD CLASSIFICATION OF OCCUPATION: MAJOR GROUPS AND SUB-MAJOR GROUPS}

\section{Managers}

11 Chief executives, senior officials and legislators

12 Administrative and commercial managers

13 Production and specialised services managers

14 Hospitality, retail and other services managers.

\section{Professionals}

21 Science and engineering professionals

22 Health professionals

23 Teaching professionals

24 Business and administration professionals

25 Information and communications technology professionals

26 Legal, social and cultural professionals.

\section{Technicians and Associate Professionals}

31 Science and engineering associate professionals

32 Health associate professionals

33 Business and administration associate professionals

34 Legal, social, cultural and related associate professionals

35 Information and communications technicians.

\section{Clerical Support Workers}

41 General and keyboard clerks

42 Customer services clerks

43 Numerical and material recording clerks

44 Other clerical support workers. 


\section{Service and Sales Workers}

51 Personal service workers

52 Sales workers

53 Personal care workers

54 Protective services workers.

\section{Skilled Agricultural, Forestry and Fishery Workers}

61 Market-oriented skilled agricultural workers

62 Market-oriented skilled forestry, fishing and hunting workers

63 Subsistence farmers, fishers, hunters and gatherers.

\section{Craft and Related Trades Workers}

71 Building and related trades workers, excluding electricians

72 Metal, machinery and related trades workers

73 Handicraft and printing workers

74 Electrical and electronic trades workers

75 Food processing, wood working, garment and other craft and related trades workers.

\section{Plant and Machine Operators, and Assemblers}

81 Stationary plant and machine operators

82 Assemblers

83 Drivers and mobile plant operators.

\section{Elementary Occupations}

91 Cleaners and helpers

92 Agricultural, forestry and fishery labourers

93 Labourers in mining, construction, manufacturing and transport

94 Food preparation assistants

95 Street and related sales and service workers

96 Refuse workers and other elementary workers.

\section{REFERENCES}

Averett, Susan (2001) Moonlighting: Multiple Motives and Gender Differences. Applied Economics 33:11, 1391-141.

Arendt, J. N and A. Holm (2006) Probit Models with Binary Endogenous Regressors. University of Copenhagen. Department of Economics. Centre for Applied Microeconometrics in its series CAM Working Papers with number 2006-06

Berman, P. and D. Cuizon (2004) Multiple Public-Private Jobholding of Health Care Providers in Developing Countries: An Exploration of Theory and Evidence. Department for International Development Health Systems Resource Centre.

Krishnan, Pramila (1990) The Economics of Moonlighting: A Double Self-selection Model. Review of Economics and Statistics 72:2, 361-67. 
Kimmel, J. and Powell (1999) Moonlighting Trends and Related Policy Issues in Canada and the United States. Canadian Public Policy 25:2, 207-31.

Kimmel, J and K. S Conway (1995) Who Moonlights and Why? Evidence from the SIPP, Upjohn Institute. (Staff Working Paper 95-40).

Murphy, Kevin M. and Robert H. Topel (1985) Estimation and Inference in Two-step Econometric Models. Journal of Business and Economic Statistics 3:4, 370-379.

O’Connell, John F. (1979) Multiple Job Holding and Marginal Tax Rates. National Tax Journal 32:1, 73-76.

Paxson, Christina H. and Nachum Sicherman (1994) The Dynamics of Job Mobility and Dual-job Holding. NBER (Working Paper No. 4968).

Shishki, Robert and Bernard Rostker (1976) The Economics of Multiple Job Holding. American Economic Review 66:3, 298-308.

Stinson, J. F. (1990) Multiple Jobholding up Sharply in the 1980's. Monthly Labour Review 3-10.

Yatchew, Adonis and Zvi Griliches (1985) Specification Error in Probit Models. The Review of Economics and Statistics 67:1, 134-139. 